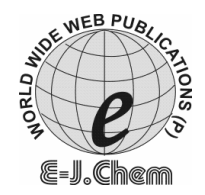

http://www.e-journals.net
ISSN: 0973-4945; CODEN ECJHAO

E-Journal of Chemistry

Vol. 5, No.4, pp. 940-945, October 2008

\title{
Recovery of Glycerol from Spent Soap Lye By - Product of Soap Manufacture
}

\author{
A.U. ISRAEL, I.B. OBOT* ${ }^{*}$ and J.E. ASUQUO \\ Department of Chemistry, \\ Faculty of Science, University of Uyo, \\ P.M.B. 1017, Uyo, Nigeria. \\ proffoime@yahoo.com
}

Received 16 October 2007; Accepted 10 December 2007

\begin{abstract}
Three samples of spent lye from soap manufacturing companies namely Paterson Zochonis Industries (PZ), International Equitable Association (IEA), Kitchen Soap Industries (KSI) all in Aba, Abia State of Nigeria and one laboratory simulated sample (SSL) were analyzed for the amount of glycerol and residual salts. The amount of glycerol in all the samples increases in the order bleached glycerin $>$ crude glycerin $>$ semi-crude glycerin $>$ treated lye $>$ spent soap lye while the reverse is the order for the amount of residual salts. For the SSL, PZ, IEA and KSL samples, the percentage of recovered glycerol were $91.00,83.20,82.80$ and 81.40 while the residual salt content (\%) were 9.80, 6.00, 7.08 and 8.03 respectively. These values compare well with international standards. The results show that the amount of the recovered glycerin and residual salts depend on the quality of the spent lye and the technology employed in the recovery treatment used.
\end{abstract}

Keywords: Glycerol, Soap, Spent soap-lye, Recovered glycerin.

\section{Introduction}

Glycerol (propan-1, 2, 3-triol) is an important by-product of soap manufacture. It is found dissolved in the soap lye and as impurity in the crude soap when fats and oils are saponified by caustic soda ${ }^{1-3}$. The process of soap manufacture from fats and oil usually yield glycerol to about $10 \%$ of the value of the soap formed and because of its many uses, its recovery is vital to the manufacturing cost analysis for any soap making venture. Unfortunately many small scale and medium scale soap producers usually discard the lye as a waste. Glycerol occurs in nature combined in the form of triglycerides (fats and oil) and is 
obtained during saponification of these triglycerides ${ }^{4}$. This process was the only means of producing commercial glycerol until 1949 when synthetic glycerol was produced as the compound recovered as by-product from the soap manufacture was not sufficient for the world consumptiom. Today glycerol is synthesized from propene by the alternate chlorination and hydroxylation process 5 . It is also obtained from fermentation of various sugars ${ }^{6}$.

Some of the major industrial applications of glycerol include the manufacture of alkyd resins and flexible polyurethane for the plastic industry. It is also an important ingredient in cosmetics and adhesive manufacture. Many pharmaceutical preparations such as glycerolphenol mixture which serves as bacteriological culture medium and glycerol derivatives (e.g. nitro glycerol) used as tranquilizers utilize glycerol.

Glycerol residue has been reported to contain $20.2 \%$ glycerol, $6.6 \%$ fatty acids (as soap) and $64.3 \%$ salt $^{1}$. Thus $91.1 \%$ of it is potentially useful. It is obviously advantageous, both environmentally and economically, to recover the glycerol in the waste (spent soap lye) for use. The present work is aimed at practically exploiting these wastes materials from soap industries as a potential alternative for the production of glycerol using chemical methods.

\section{Experimental}

Spent soap lye which is a mixture of many compounds namely glycerol 6-16\%, salt 10-12\%, caustic soda $0.3-0.8 \%$, total fatty matter $0.4 \%$ and water $39-40 \%$. Others are organic and inorganic impurities such as resins, arsenic and arsenic compounds ${ }^{7}$, were obtained from three industries in Aba, Abia State in Nigeria. The industries include Paterson Zochonis Industries (PZ), International Equitable Association (IEA), Kitchen Soap Industries (KSI) and the Laboratory Simulated Soap sample (SSL). Other reagents of Analytical grade from British Drug House (BDH) were used as purchased in the analysis.

\section{Preparation of laboratory simulated soap sample (SSL)}

Palm oil $(200 \mathrm{~mL})$ was added to caustic soda $(\mathrm{NaOH})$ slowly with constant stirring to obtain a smooth paste. The soap was grained with some quantity of brine which separated the soap mass from excess water containing glycerol, sodium hydroxide, salt and other impurities. This spent soap lye labeled sample SSL was preserved for analysis.

\section{Treatment of spent soap lyes}

Spent soap lyes samples (200mL) (PZ, IEA, KSI, SSL) were first analysed for percentage caustic soda, salt, glycerol, total fatty matter, other impurities and moisture by the method of Igile ${ }^{8}$ as described below. The left over liquor after soap manufacture (lye) was allowed to settle for 20minutes in each case after stirring with a rod. The clear phase was decanted from the sample and heated to $60^{\circ} \mathrm{C}$ in a conical flask. Acid treatment was followed by addition of dil. $\mathrm{HCl}(0.1 \mathrm{M})$ dropwisely until the $\mathrm{pH}$ was between 5.0-6.0. The sample was later filtered into a conical flask. Sodium hydroxide solution $(0.1 \mathrm{~mL})$ was added with the aid of a pipette to the filtrate obtained above to raise the $\mathrm{pH}$ again to between 8.0-9.0. The sample was filtered again and the filtrate was analyzed for percentage caustic soda, salt and glycerol. The semi-crude glycerin was obtained by evaporating the filtrate above under vacuum pressure $(80 \mathrm{mmHg})$. The resultant crude glycerin was for analyzed for percentage salt, glycerin, moisture and impurities. Salt was recovered from the crude glycerin by allowing the sample to stand for $4 \mathrm{~h}$ after which the clear phase was decanted for the salt. 


\section{Bleaching of crude glycerin}

This was carried out using the method of Igile ${ }^{10}$. Crude glycerin with bleaching earth (3\%) and $0.1 \%$ of $\mathrm{H}_{2} \mathrm{SO}_{4}(10 \mathrm{~mL})$ were introduced into a round bottomed flask. Heat was supplied with continuous stirring for 30 minutes under vacuum $(120 \mathrm{mmHg})$ and $90^{\circ} \mathrm{C}$. Calcium carbonate $(0.05 \%)$ was added to neutralize the content of the flask. The content was cooled to $70^{\circ} \mathrm{C}$ and filtered. This is bleached glycerin and was analysed for percentage glycerin, salt, moisture content and impurities. Bleached glycerin was further purified by vacuum distillation in order to obtain purified glycerin with high concentration. The distillate (purified glycerin) was collected and analyzed for percentage glycerin and salt.

\section{Determination of salt content in the spent soap lye}

Untreated and treated soap lye sample $(0.1 \mathrm{~g})$ was weighed into a conical flask $(250 \mathrm{~mL})$ containing distilled water $(100 \mathrm{~mL})$. Methyl orange indicator (2-3 drops) was added to the mixture. A drop of dilute nitric acid $(0.1 \mathrm{M})$ was added to neutralize the sample. This was followed by the addition of potassium dichromate $(2 \mathrm{~mL})$ as the sample colour changed to yellow. The sample content was titrated with silver nitrate solution $(0.1 \mathrm{M})$. The end point was detected with a colour change from yellow to light brown. From the result obtained, the percentage salt was calculated ${ }^{8}$.

\section{Percentage free caustic soda in lye}

$10 \mathrm{~g}$ of soap lye was weighed and diluted to $100 \mathrm{~mL}$ with distilled water. Phenolphthalein indicator (2-3) drops was added, the colour changed to pink. The same was neutralized by adding barium chloride $(5 \mathrm{~mL})$. The solution was titrated with hydrochloric acid $(0.1 \mathrm{M})$ to obtain a colourless solution at the end point. The percentage caustic soda $(\mathrm{NaOH})$ was determined as volume of $\mathrm{HCl}(0.1 \mathrm{M})$ multiplied by conversion factor of $0.04 \%{ }^{10}$.

\section{Percentage concentration of glycerol in crude glycerin}

$5.0 \mathrm{~g}$ of the sample were taken into a conical flask and $50 \mathrm{~mL}$ of distilled water was added. A blank (control sample) was set up with $50 \mathrm{~mL}$ water at the same time. Phenol red indicator (10 drops) was added to obtain yellow colour. $0.1 \mathrm{M} \mathrm{HCl}(1.0 \mathrm{~mL})$ was added to neutralize the contents of the flask. The sample was left to stand for 20 minutes in a dark chamber. The sample was then titrated with $0.1 \mathrm{M} \mathrm{NaOH}$ to pink colour as the end point taking the blank sample first.

The concentration of glycerol was calculated as percentage of glycerol in the crude glycerin using the titration value according to equation (1) as reported by ${ }^{8}$.

$$
C_{a}=\frac{V_{s}-V_{b}}{W_{s}} \times 0.92
$$

where $\mathrm{C}_{\mathrm{a}}$ is the percentage concentration of glycerol, $\mathrm{V}_{\mathrm{s}}$ is the volume of $0.1 \mathrm{M} \mathrm{NaOH}$ added to the sample, $\mathrm{V}_{\mathrm{b}}$ is the volume of $0.1 \mathrm{M} \mathrm{NaOH}$ added to the blank and $\mathrm{W}_{\mathrm{s}}$ is the weight of sample.

Percentage impurities in the sample were determined by pouring the whole sample into a measuring cylinder and allowing it to settle for $1 \mathrm{~h}$. The percentage impurity was calculated from the equation (2) as reported by Igile ${ }^{8}$.

$$
\% \text { Impurity = Level of impurity in cylinder } \quad X 100
$$




\section{Results and Discussion}

Table 1 shows the estimated consumption of glycerin in various industries. Table 2 shows the Glycerin Producers Association Standards for Glycerin recovery. Table 3 shows the percentage concentrations of salt and glycerin and their standard deviations recovered from Soap Lye for different samples (SSL, PZ, IEA and KSI), while Table 4 shows the standard deviation for $\%$ salt and $\%$ glycerin for samples at different stages respectively.

Table 1. Estimated consumption of glycerin in various industries ${ }^{11}$

\begin{tabular}{|c|c|}
\hline Industry & Percentage use \\
\hline Alkyd resin & 30.00 \\
\hline Tobacco (humectants) & 12.00 \\
\hline Explosives & 12.00 \\
\hline Cellophane & 11.20 \\
\hline Cosmetics/Mouthwashes & 5.10 \\
\hline Pharmaceuticals & 5.10 \\
\hline Sealants, Lubricants & 4.60 \\
\hline $\begin{array}{l}\text { Various intermediates for synthetic } \\
\text { dyes, Lacquers, textiles }\end{array}$ & 20.00 \\
\hline
\end{tabular}

Table 2. Glycerin Producers Association Standards for glycerin recovery ${ }^{7}$

\begin{tabular}{lll}
\hline State of Recovery & \% Salt & \% Glycerin \\
\hline Spent soap lye & $10-12$ & $6-16$ \\
Treated lye: Acid, (Alkaline) & $11-13,(16-18)$ & $5-7,(8-10)$ \\
Semi-Crude Glycerin & $19-22$ & $30-45$ \\
Crude Glycerin & $8-10$ & $80-84$ \\
Bleached Crude Glycerin & $6-9$ & $85-91$ \\
Purified Glycerin & $9-10$ & 92 \\
\hline
\end{tabular}

Table 3. Percentage concentrations of salt and glycerin and their standard deviations recovered from soap lye for different samples (SSL, PZ, IEA and KSI)

\begin{tabular}{lcccccccc}
\hline Samples & SSL & \multicolumn{3}{c}{ PZ } & \multicolumn{3}{c}{ IEA } & \multicolumn{3}{c}{ KSI } \\
\hline $\begin{array}{l}\text { Spent Soap } \\
\text { Lye }\end{array}$ & 9.30 & 15.00 & 9.59 & 7.31 & 10.50 & 5.48 & 9.48 & 7.29 \\
$\begin{array}{l}\text { Treated Lye } \\
\text { Semi Crude }\end{array}$ & 17.00 & 10.00 & 9.75 & 7.95 & 12.90 & 6.15 & 9.04 & 7.08 \\
$\begin{array}{l}\text { Gly. } \\
\text { Crude }\end{array}$ & 22.00 & 40.00 & 10.52 & 30.10 & 15.50 & 42.46 & 11.13 & 40.05 \\
$\begin{array}{l}\text { Glycerin } \\
\text { Bleached }\end{array}$ & 8.00 & 81.00 & 6.40 & 82.80 & 7.49 & 81.57 & 8.13 & 80.40 \\
$\begin{array}{l}\text { Glycerin } \\
\text { Standard }\end{array}$ & 9.80 & 91.00 & 6.00 & 83.20 & 7.08 & 82.80 & 8.03 & 81.40 \\
Deviation & 3.66 & 37.01 & 1.67 & 34.28 & 3.29 & 34.22 & 1.22 & 34.78 \\
\hline
\end{tabular}

From Table 3, the amount of percent glycerin $(\%)$ in all the samples increases in the order: bleached $>$ crude glycerin $>$ semi-crude glycerin $>$ spent lye $>$ treated lye respectively, while the reverse is the order for the amount of residual salts. The percentage of glycerin recovered for the various samples- SSL, PZ, IEA and KSI were 91.00, 83.20, 82.80 and 81.40 respectively. These figures compare well with the standard value obtained 
by the Glycerin Producers Association of the American Chemical Society (Table 2) in which the percentage recovered glycerin ranges between $85-91 \%$. It can be seen from Table 3 that the amount of glycerin obtained depends on the stage of recovery. The bleaching action yields the highest quantity of glycerin (Table 3). This is because the bleaching action (alkaline system) not only purifies the substance but also concentrates it by saponifying free triglycerides to increase the glycerol concentration ${ }^{9}$. Thus, the amount of recovered glycerol depends on the point of recovery and on the stages of purification ${ }^{8}$.

The variation in amount of glycerin recovered from spent soap lye from the various industries depends on the nature of the soap lye and the method of treatment. During the recovery stages, glycerin can be lost through a number of ways such as washing, graining and desalting. If the optimum temperature of $60^{\circ} \mathrm{C}$ is exceeded during treatment, side reactions may occur. Thus glycerol may decompose to acrolein at higher temperatures as shown:

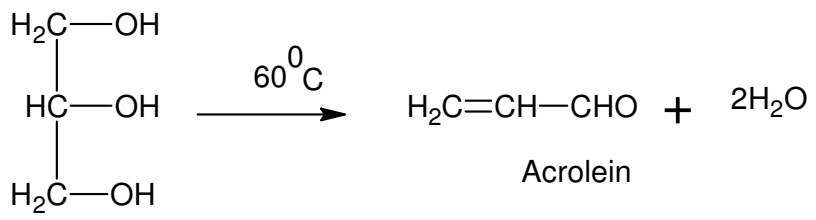

\section{Glycerol}

Other sources of glycerin losses during the recovery operations include filtration process $(1 \%)$, evaporation $(1 \%)$ and salt recovery $(0.3 \%)$. The total loss in the recovery from spent soap lye to pure glycerin will run to about $2.5-3.0 \%$ of glycerin in the soap lye. This fraction accounts for the different results obtained for percentage glycerin recovered from the various samples. Table 3 also shows that the amount of residual salts recovered for the samples: SSL, PZ, IEA and KSI were 9.80, 6.00, 7.08 and 8.03 respectively. Again the quantities of residual salts depend on the point of recovery and the nature of lye treatment. The acid and alkaline treatments of the soap lye in adjusting the $\mathrm{pH}$ of the lye helps to reduce the amount of salt originally combined with the soap by precipitation, coagulation and flocculation ${ }^{10}$.

Table 4. Standard deviation for $\%$ salt and $\%$ glycerin for samples at different stages stages of recovery

\begin{tabular}{|c|c|c|c|c|c|c|}
\hline & & \multicolumn{4}{|c|}{ Samples } & \multirow{2}{*}{$\begin{array}{l}\text { Standard } \\
\text { Deviation }\end{array}$} \\
\hline & & SSL & $\mathrm{PZ}$ & IEA & KSI & \\
\hline \multirow{2}{*}{ Spent Soap Lye } & $\%$ Salt & 9.30 & 9.59 & 10.50 & 9.48 & 1.82 \\
\hline & \% Gly. & 15.00 & 7.31 & 5.48 & 7.29 & 3.64 \\
\hline \multirow{2}{*}{ Treated Lye } & $\%$ Salt & 17.00 & 9.75 & 12.90 & 9.04 & 3.14 \\
\hline & \% Gly. & 10.00 & 7.95 & 6.15 & 7.08 & 1.43 \\
\hline \multirow[t]{2}{*}{ Semi Crude Gly. } & $\%$ Salt & 22.00 & 10.52 & 15.50 & 11.13 & 4.66 \\
\hline & \% Gly. & 40.00 & 30.10 & 42.46 & 40.85 & 7.92 \\
\hline \multirow[t]{2}{*}{ Crude Glycerin } & $\%$ Salt & 8.00 & 6.40 & 7.49 & 8.13 & 0.68 \\
\hline & \% Gly. & 81.00 & 87.80 & 81.57 & 88.40 & 2.94 \\
\hline \multirow[t]{2}{*}{ Bleached Gly. } & $\%$ Salt & 9.80 & 6.00 & 7.08 & 8.03 & 1.38 \\
\hline & \% Gly. & 1.00 & 83.20 & 82.80 & 81.40 & 3.75 \\
\hline
\end{tabular}

The Standard Deviation (S.D) values for glycerin recovered from spent soap lye from various samples are presented in Table 4. Table 4 also shows Standard Deviation (S.D) 
values for percentage (\%) salt and percentage $(\%)$ glycerin for sample at different stages of recovery. The Standard Deviation (S.D) value which is precision index is greater than zero which indicates that little or negligible experimental errors were made or observed in the experiments whereas Standard Deviation of zero indicates absolute precision. The (S.D) values however, were in order considering at least three or triplicate determinations were made for each sample. Thus, it should be noted that the reliability of any calculated quantity depends on the reliability of the data that went into the calculation and on the number of measurements made ${ }^{1}$.

\section{Conclusion}

This study shows that treatment and quality of spent soap lye affect the quality and quantity of glycerin from the soap lye. With the high demand for glycerin in various industries, optimum method should be adopted in the recovery of glycerin. The spent soap lye should pass through all the processes of purification in order to obtain high quality glycerol yield during the recovery process. Glycerin should be removed from the soap lye because if left in the soap it will limit the washing qualities of the soap. In this way, glycerol is produced for other industrial applications while the properties of soap are enhanced by absence of glycerol. The recovered salt is reused in the soap graining operations. Therefore glycerol recovery from spent soap lye is of economic importance to both the soap manufacturers and consumers as well.

\section{Acknowledgement}

The authors wish to thank the management of Paterson Zochonics Plc (PZ), Aba, Abia State, Nigeria for helping in some of the analysis with the help of Mrs. Uchenna Stephanie of Chemistry Department, University of Uyo, Akwa Ibom State, Nigeria.

\section{References}

1. Ooi T L, Yong K C, Hazimah A H, Dzulkefty K and Wan-Yunus W M Z, J Oleo Sci., 2004, 53, 29-33.

2. $\quad$ Young F V K, J Am Oil Chem Soc., 1983, 60, 326-331

3. Whalley G R, Happi, 1993, 6, 92-96.

4. Parker S P, (ed.) Glycerin: Encyclopedia of Science and Technology, $6^{\text {th }}$ Ed., McGraw Hill Inc., New York, 1987, 124-127.

5. Tedder J M and Nechatal A, Basic Organic Chemistry, Part 2, Longman, London, $1973,130$.

6. Tewari K S, Mehrotra S N and Vishnoi N K, A Textbook of organic Chemistry, Vikas, New Delhi, 1980, 469.

7. Dalton N N, Kern J C and Miner C S (Eds.), Glycerol: Encyclopedia of Chemical Technology, $1^{\text {st }}$ Ed., Association of American Soap and Glycerin Products, U.S.A, 1973, 215-229.

8. Igile G, Manual on Glycerin Recovery, Paterson Zochonis Industries Plc, Aba, Nigeria, 1993, 3.

9. Grant M and Hawkins R (Eds), Concise Lexion of Environmental Terms, Wiley and Sons Inc., New York, 1989, 719.

10. Igile G, Lye Treatment and Glycerin Recovery, Paterson Zochonis Industries Plc, Aba, Nigeria, 1995, 24.

11. Henglcin F A, Chemical Technology, $1^{\text {st }}$ Ed., Pergamon Press Ltd., London, 1966, 680. 


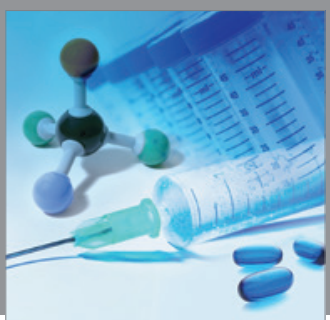

International Journal of

Medicinal Chemistry

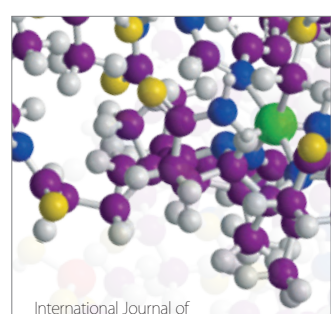

Carbohydrate Chemistry

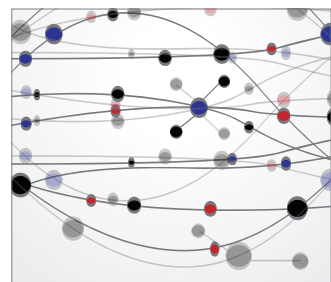

The Scientific World Journal
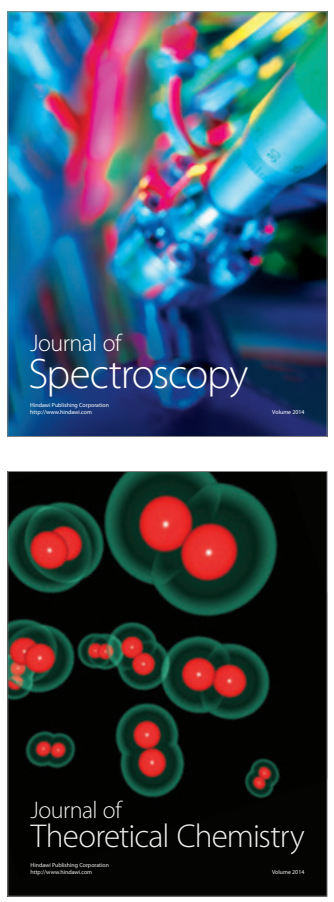
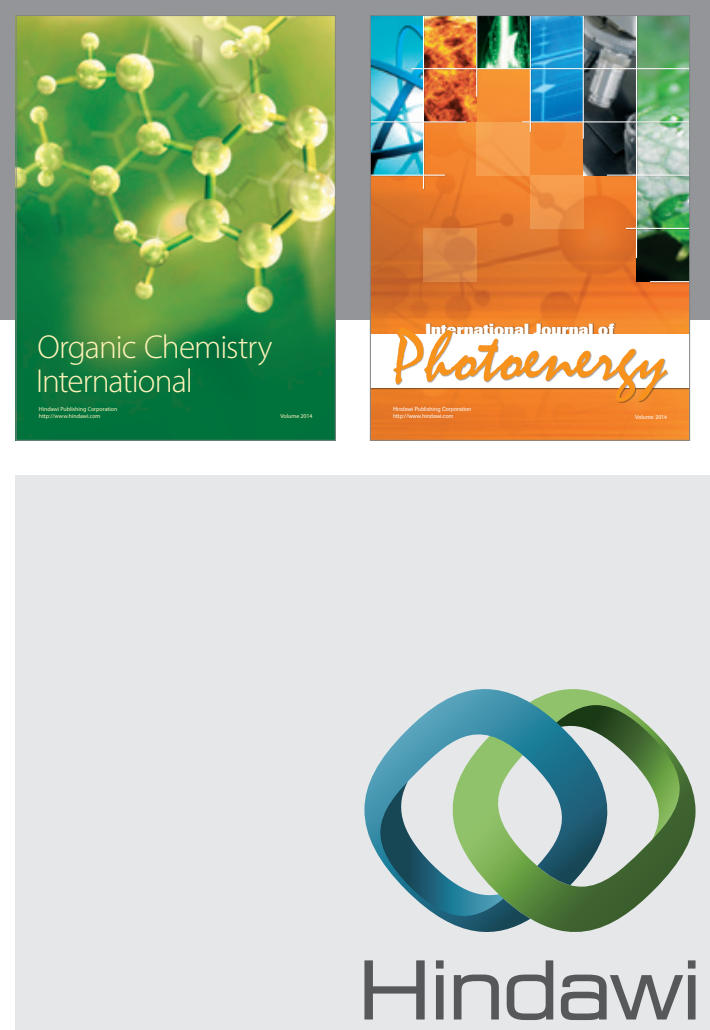

Submit your manuscripts at

http://www.hindawi.com
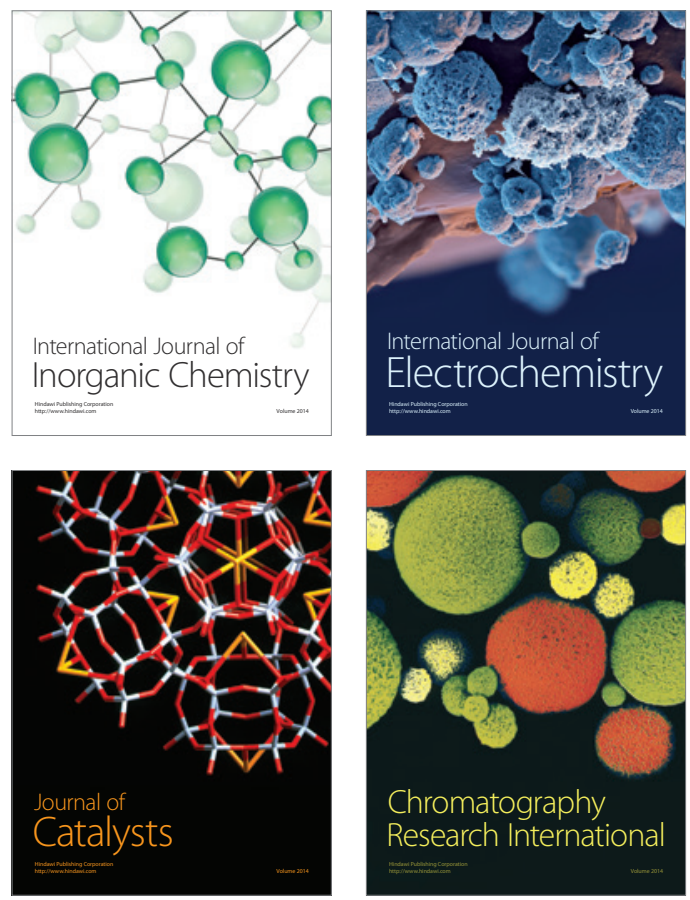
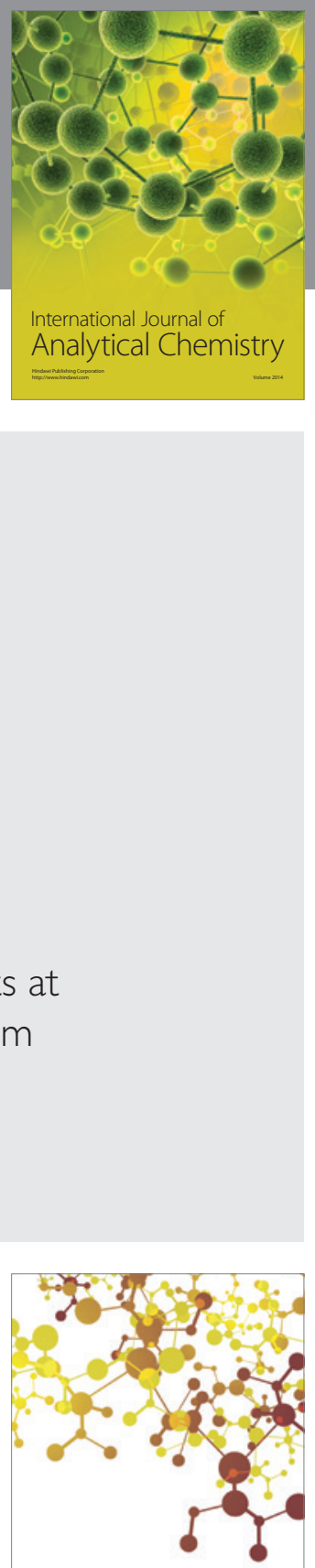

Journal of

Applied Chemistry
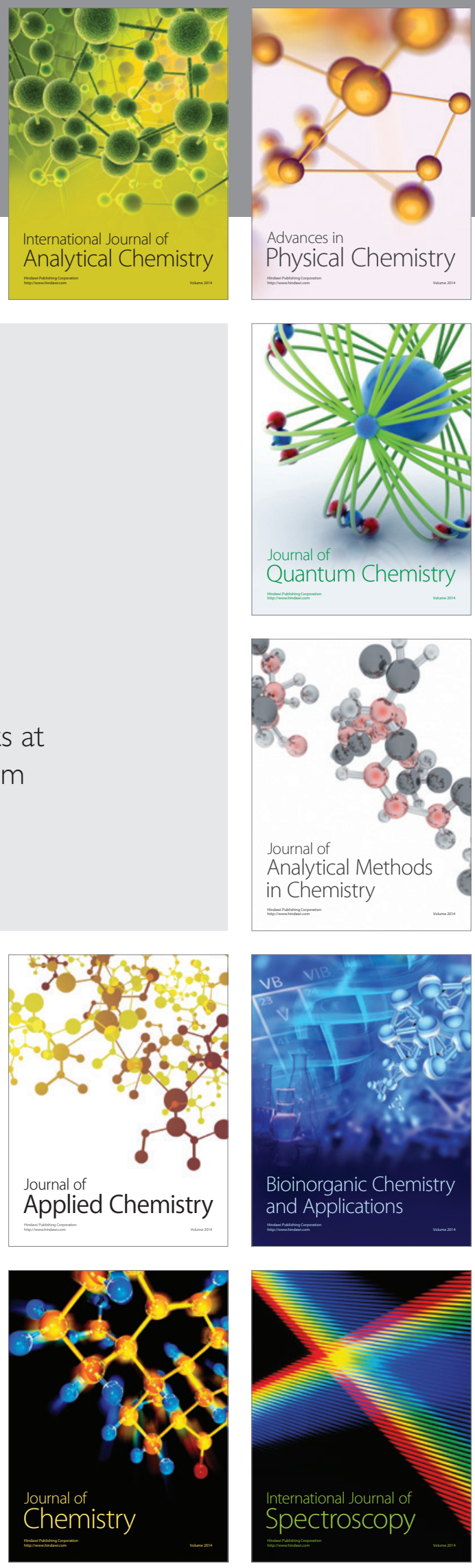